\title{
International Journal of Advancement in Life Sciences Research
}

Online ISSN: 2581-4877

Original Article

\section{Effect of Vitamin C \& E on Enzyme Glutathione Peroxidase Activity (GSH-PX) in Male Wistar Strain Rats Exposed to Carbon Tetrachloride $\left(\mathrm{CCl}_{4}\right)$}

Titin Ifayanti *

Lecturer, STIKes Alifah Padang, Indonesia

*Correspondence E-mail : titin.titinifayanti@yahoo.com

\begin{abstract}
The free radicals are the cause of cell damage that underlies the emergence of various degenerative diseases. Having an abundant amount of free radicals can cause oxidative stress. Carbon tetrachloride, including chemicals that are metabolized in the liver, its metabolism result is free radical. Its needed to anticipate the damage to the liver. So that, it is needed to have antioxidants from outside to increase the cells defence as neutralizer free radicals like vitamin $\mathrm{C}$ and $\mathrm{E}$.

The purpose of this study was to determine the effect of vitamin $C$ and $E$ on glutathione peroxidase enzyme activity on rats exposed to carbon tetrachloride.

The research was conducted experimentally with post test only control group design. The study sample consisted of 25 male wistar strain rats weighing $165-210 \mathrm{~g}$, divided into 5 groups: negative control, positive control $\left(\mathrm{CCl}_{4}\right)$, treatment I $\left(\mathrm{CCl}_{4}\right.$ and Vitamin $\left.\mathrm{C}\right)$, treatment II $\left(\mathrm{CCl}_{4}\right.$ and Vitamin $\left.\mathrm{E}\right)$, treatment III $\left(\mathrm{CCl}_{4}\right.$, combination of vitamins $\mathrm{C}$ and $\left.\mathrm{E}\right) . \mathrm{CCl}_{4}$ was given a single dose of $0.2 \mathrm{mg} / \mathrm{kg}$, the next 24 hours are given Vitamin C $0.8 \mathrm{mg} / \mathrm{kg}, 0.8 \mathrm{ml}$ vitamin $\mathrm{E} / \mathrm{kg}$ and a combination of vitamins C $0.8 \mathrm{mg} / \mathrm{kg}$ and $0.8 \mathrm{ml} / \mathrm{kg}$, administered orally for 14 days. Data were analyzed with a confidence level of $95 \%$.

The Results of the study showed the average activity of the enzyme glutathione peroxidase was negative group $114.4 \pm 5.5 \mathrm{nmo} / \mathrm{ml}$, positive group $96 \pm 7.4 \mathrm{nmo} / \mathrm{ml}$, the first treatment $129.2 \pm 5.4$ $\mathrm{nmo} / \mathrm{ml}$, the second treatment $140.2 \pm 3.2 \mathrm{nmo} / \mathrm{ml}$, the third treatment $156 \pm 4.2 \mathrm{nmo} / \mathrm{ml}$.

It is concluded that vitamin $\mathrm{C}$ and $\mathrm{E}$ can increase the glutathione peroxidase activity in rats exposed to carbon tetrachloride. It is need to do more research on the effect of vitamin $C$ and $E$ to see the existing network of the liver.
\end{abstract}

Keywords: Carbon Tetrachloride, Glutathione Peroxidase, Vitamin C and E

\section{Introduction}

Free radicals are one of the causes of various degenerative diseases, such as cardiovascular, high blood pressure, stroke, liver cirrhosis, cataracts, diabetes mellitus and cancer. Free radicals can be produced from inside the body and outside the body. Free radicals can damage macromolecules such as damage to cell membrane lipids, DNA, and proteins that cause oxidative stress cells (Valko, 2006).

Hovewer, in some circumstances where there is an increase in free radicals caused by triggers, there can be a negative impact on liver cells (Cochrane, 1991). The 
chemicals that have been known to increase free radicals are carbontetrachloride $\left(\mathrm{CCl}_{4}\right)$. However, in some circumstances where there is an increase in free radicals, it can be a negative impact on liver cells (Cochrane, 1991).

Liver disease is classified as one of the degenerative diseases which is a national problem in Indonesia and developing countries in general. Based on reports from all RSUP types $A$ and $B$ throughout Indonesia, liver disease ranks third after infectious diseases and lung diseases. In addition, from the World Health Organization data (WHO, 2007), chronic liver disease and liver cirrhosis were the twelve leading causes of death in 2007 in the United States with a total of 29,165 (1.2\%). In 2007, the prevalence of Liver Cirrhosis in Australia was $2 \%$ and in Japan it was $2.7 \%$ (Farrell, 2008).

Carbontetrachloride $\left(\mathrm{CCl}_{4}\right)$ is a chemical compound, which can cause damage to liver and kidney tissue (Ogeturk et al, 2004). $\mathrm{CCl}_{4}$ toxicity has been proven from several studies, that even the smallest dose can have an effect on liver tissue. Liver damage due to $\mathrm{CCl}_{4}$ exposure depends on the dose given (Halliwell and Gutteridge, 2004).

Carbontetrachloride is produced in large quantities, for example in the manufacture of refrigator / refrigerant liquids, propellants for aerosol cans, pesticides, stain cleaning fluids and used for fire suppression (ATSDR, 2005). The hepatotoxic effect of $\mathrm{CCl}_{4}$ depends on the metabolic activity of $\mathrm{CCl}_{4}$ which takes place in the endoplasmic reticulum of the liver cells through interaction with NADPH electron transport cytochrome P450. Based on the Dahiru study (2003), the dose of CCL4 with a single dose of $1.0 \mathrm{mg} / \mathrm{kg}$ body weight can cause an increase in the activity of the enzyme SGPT, SGOT and total protein in the liver of experimental rats.

In facing free radical attacks, body has a protective mechanism through the body's antioxidant system. In general antioxidants are divided into two, namely enzymatic antioxidants that come from the body (endogenous), namely enzyme superoxide dismutase (SOD), catalase, glutathione peroxidase (GSH-px), and non-enzymatic antioxidants that come from outside in body (exogenous), namely Vitamin C, Vitamin E, beta-carotene, and flavonoids obtained from plants (Chevion et al., 2003).

Enzymatic (endogenous) antioxidants such as Glutathione peroxidase (GSH-px) are enzymes that function to metabolize hydrogen peroxide $\left(\mathrm{H}_{2} \mathrm{O}_{2}\right)$. The mechanism of the GSH-px enzyme is one of the main ways used by the body to protect itself from oxidative damage. This enzyme catalyzes the reduction of hydrogen peroxide and peroxide fat $(\mathrm{LOOH})$ by glutathion (glglutamyl-isteinsintetase) (Montgomery et al, 1991).

Glutathione peroxidase activity in the human body varies depending on the tissue. The activity of glutathione in the blood is in the range of 0.5-8 millimolar mol / I with the highest concentration in the liver whereas in rat liver normally contains 7-8 $\mu \mathrm{mol}$ GSH / $\mathrm{g}$ tissue. Plasma glutathione is only $0.5 \%$ of what is contained in the blood while in erythrocytes it contains $99.5 \%$. In eukaryotes, $90 \%$ of glutathione is found in the cytosol, $10 \%$ is in mitochondria, and some percent are in the endoplasmic reticulum (Daruningrum, 2012). In a state of oxidative stress, the concentration of glutathione peroxidase will decrease which can be caused by the use of glutathione in counteracting the free radicals (Youngson, 2005).

Non-enzymatic antioxidants are exogenous antioxidants derived from food ingredients such as Vitamin C, Vitamin E, betacarotene and flavonoids obtained from plants. Shortage of one of these components can cause a decrease in the overall antioxidant status so that the body's protection against free radicals is reduced (Chevionet al, 2003).

Non enzymatic antioxidants are exogenous antioxidants, one of the enzymatic antioxidants is Vitamin $\mathrm{C}$ and Vitamin $\mathrm{E}$.

Vitamin $\mathrm{C}$ is an aqueous antioxidant. The role of vitamin $\mathrm{C}$ as an antioxidant in donating electrons to intracellular and extracellular biochemical reactions so that vitamin $\mathrm{C}$ is able to remove reactive oxygen 
compounds in cells. In addition, vitamin $\mathrm{C}$ is also needed in several processes in the body such as biosynthesis, cartinin which transfers fat, adrenaline, cortison, electron transport in many enzymatic reactions, protects the gums and improves immune function (Gropper, 2013).

The strength of Vitamin $\mathrm{C}$ as a water-soluble antioxidant is due to the ability of Vitamin $\mathrm{C}$ to reduce superoxide to hydrogen peroxide or $\mathrm{Fe}^{-}$to $\mathrm{Fe}^{-}$, or the reduction of other metal elements. After a single electron transfer, Vitamin C produces monodehydroascorbate radicals. This radical will change to ascorbate and dehydroascorbate. Most body tissues have the enzyme glutathione dependent monodehydro ascorbate reductase and NADPH which will reduce the radical to ascorbate again. Dehydroascorbate is unstable in solution, and it will experience the breakdown of the ring group into diketogulonic acid. However, dehydroascorbate is usually reduced by NADPH or glutathione dependent reductase to ascorbate (Bender, 2003).

Vitamin $E$ (a-tochoperol) is a fat-soluble vitamin and very potential as an antioxidant. $\alpha$ tochoperol breaks the chain in preventing propagation from free radicals (Ramanathan, 2005). Vitamin E (a-tocopherol) has been widely documented as an antioxidant that has a high ability to protect cells from free radicals. The main biological role of Vitamin $E$ is to break the chain of lipid peroxidation processes by donating one hydrogen atom from the $-\mathrm{OH}$ group to the ring to free radicals so that the formation of a stable and non-destructive Vitamin E radical is formed (Almatsier, 2009).

In vivo and In Vitro, vitamin $\mathrm{E}$ antioxidants affect oxidative lead poisoning in erythrocytes in rats showing Vitamin $E$ prevents inhibition of $\delta$-aminolevulinic dehydrate enzyme activity and lipid oxidation (Rendon, 2007). Vitamin E is useful in protecting lipid membranes and preventing protein oxidation from lead intoxication.

Vitamin $E$ also has the main function as a chain-breaking antioxidant. Vitamin $\mathrm{E}$ gives hydrogen from the hydroxyl group ( $\cdot \textrm{OH})$ to the structure of free radicals, so that free radicals become nonreactive. Vitamin E stops the fat peroxidation of free radicals by giving a single electron to form quinone tokoferol which is stable and perfectly oxidized therefore the presence of Vitamin $\mathrm{E}$ in the body is indispensable (Ernawati, 2009).

The aim of the study was to determine the effect of vitamin $E$ on the activity of glutathione peroxidase (GSH-px) in Wistar strain rats exposed to carbon tetrachloride $\left(\mathrm{CCl}_{4}\right)$.

\section{Methodology}

This research was carried out experimentally with a research design that is Post Test Only Control Group Design which is a design used to measure the effect of treatment on the experimental group by comparing the treatment group with the control group. The treatments used were control (without treatment), rats exposed to carbon tetrachloride (CCL4), rats exposed to CCL4 and Vitamin C, rats exposed to CCL4 and Vitamin E, and rats exposed to CCL4 and a combination of Vitamin $C$ and Vitamin E.

The population in this study were wistar strain white rats obtained from the research animal development unit (UHPH) at Faculty of Pharmacy of Andalas Padang University with the consideration that mice are mammals or often called laboratory animals because they are often used in laboratory biology research. The number of samples in each group was 5 . This study consisted of 5 groups, so the total sample size was $5 \times 5=$ 25 heads. However, as a reserve for substitutes the possibility of grouping out is $10-20 \%$, so in this study each group maintained 7 tails in order the total number of rats were 35 .

The administration of carbon tetrachloride is done 1 time (single dose). Based on the study of Dahiru (2003), $\mathrm{CCl}_{4}$ was given with a single dose of $1.0 \mathrm{mg} / \mathrm{kgBB}$. Vitamin $E$ is given every day for 14 days of treatment. The method of administration is the same as giving $\mathrm{CCl}_{4}$ by using blunt sonde through the edge of the ceiling while being pushed slowly back to the oesopagus, according to the prescribed dose. 
Glutathione Peroxidase examination was carried out at Biomedical Laboratory of Andalas PadangUniversity. Examination was done using the Elisa method.

The results of the research data obtained were Shapiro-Wilk Normality Test and Homogeneity Test. If the data was not normally distributed, it was analyzed using the Non Parametric Kruskal Wallis Test. And if the data was normally distributed, data analysis was continued using ANOVA test with 95\% confidence level. If there were significant results, then it was proceed with Bonferroni type Mutiple Comparisons (Post Hoc Test) statistical test to see the significance between groups (Sastroasmoro, 2010).

\section{Results}

This study was conducted to determine the effect of vitamin $C$ and $E$ on glutathion peroxidase activity in wistar strains rats exposed to carbon tetrachloride. After administering vitamin $C$ with a dose of $0.8 \mathrm{ml} /$ $200 \mathrm{grBB}$ and vitamin $\mathrm{E}$ with a dose of $0.8 \mathrm{ml} /$ $200 \mathrm{grBB}$ as well as a combination of vitamins $\mathrm{C}$ and $\mathrm{E}$ for 14 days, blood samples were carried out on mice to see the activity of glutathion peroxidase enzymes.

This study used 25 male rats, the study began on $21^{\text {st }}$ January 2016 to $12^{\text {th }}$ February 2016. This study was performed at the Laboratory of Pharmacy and examination of serum research was conducted at the Biomedical Laboratory of the Faculty of Medicine of Andalas Padang University on February 29, 2016. The results could be seen in table 1,2 , and 3 .

Before the data was processed statistically further, normality was tested first.

Table 1. Test for Normality of Glutathione Peroxidase Enzyme Activity (GSH-px) in animal testing

\begin{tabular}{|c|c|c|}
\hline \multicolumn{3}{|c|}{ Glutathion Peroxidase Activity } \\
\hline Average $(\mathrm{nmol} / \mathrm{ml})$ & Std. Deviation & $\mathrm{p}$ \\
\hline 133.9 & 25 & 0.46 \\
\hline
\end{tabular}

In table 1, before the data was analyzed, normality test was done for the data we had by using The Shapiro-Wilk Test. It was found that the data was normally distributed, where $p$ $=0.46(p>0.05)$.

Table 2 . Homogeneity Test of Glutathione Peroxidase Enzyme Activity (GSH-px) in animal testing

\begin{tabular}{|c|c|}
\hline \multicolumn{2}{|c|}{ Glutathion Peroxidase Activity } \\
\hline Average $(\mathrm{nmol} / \mathrm{ml})$ & $\mathrm{p}$ \\
\hline 127.1 & 0.70 \\
\hline
\end{tabular}

In table 2, before the data is analyzed, we also needed to do homogeneity test first for the data that we had. It was found that the homogeneous data variant, where $p=0.70$ $(p>0.05)$.

Table 3. Average of glutathione peroxidase activity of rats in the control group and treatment group after administration of vitamin $\mathrm{C}, \mathrm{E}$, and combination of vitamins $\mathrm{C}$ and $\mathrm{E}$

\begin{tabular}{|ccc|}
\hline Group & $\begin{array}{c}\text { Glutathion Peroxsidase } \\
\text { Activity Average } \pm \text { SD } \\
\text { (nmol/ml) }\end{array}$ & $\mathrm{p}$ \\
\hline KN & $114.4 \pm 5.5$ & \\
KP & $96 \pm 7.4$ & 0.001 \\
P1 & $129.2 \pm 5.4$ & \\
P2 & $140.2 \pm 3.2$ & \\
P3 & $156 \pm 4.2$ & \\
\hline
\end{tabular}

In table 3 , it was found that after the administration $\mathrm{CCl}_{4} 0.2 \mathrm{mg} / 200 \mathrm{grBB}$, there was an average decrease in glutathion peroxidase activity in wistar male rats in the positive group of $96 \mathrm{nmol} / \mathrm{ml}$ compared with the negative control group not given $\mathrm{CCl} 4$ which was $114.4 \mathrm{nmol} / \mathrm{ml}$. After the administration of vitamin $\mathrm{C}$, there was an average increase in glutathion peroxidase activity, which was $129.2 \mathrm{nmol} / \mathrm{ml}$, then by the administration of vitamin $E$, there was also an increase in the average activity of glutathion peroxidase $140.2 \mathrm{nmol} / \mathrm{ml}$. In addition, with the combination of vitamin $\mathrm{C}$ and vitamin $E$ there was an increase in activity of glutathione peroxidase $156 \mathrm{nmol} /$ $\mathrm{ml}$. Statistically, there were significant results $p=0.001(p<0.05)$ which meant that there was an effect of giving vitamin $C$, vitamin $E$ and a combination of vitamins $C$ and $E$ on glutathion peroxidase activity. 
Table 4. Post Hoc Bonferoni Test results on the average glutathione peroxidase activity of rats in each study group.

\begin{tabular}{|c|c|c|c|c|c|}
\hline \multirow{2}{*}{$\begin{array}{l}\text { 음 } \\
\text { 분 }\end{array}$} & \multicolumn{5}{|c|}{$\begin{array}{l}\text { Meaningfulness level of GSH-px activity } \\
\qquad(\mathrm{nmol} / \mathrm{ml})\end{array}$} \\
\hline & $\mathrm{KN}$ & $\mathrm{KP}$ & P1 & P2 & P3 \\
\hline $\mathrm{KN}$ & - & $0.000^{*}$ & $0.003^{*}$ & $0.000^{*}$ & $0.000^{*}$ \\
\hline$\overline{K P}$ & $0.000^{*}$ & - & $0.000^{*}$ & $0.000^{*}$ & $0.000^{*}$ \\
\hline $\mathrm{P} 1$ & $0.003^{*}$ & $0.000^{*}$ & - & $0.041^{*}$ & $0.000^{*}$ \\
\hline P2 & $0.000^{*}$ & $0.000^{\star}$ & $0.041^{*}$ & - & $0.002^{*}$ \\
\hline P3 & $0.000^{*}$ & $0.000^{*}$ & $0.000^{*}$ & $0.002^{*}$ & - \\
\hline
\end{tabular}

Based on the results of the Post Hoc Bonferoni test in table 4, it was found that in each treatment group with the provision of vitamin $C$, vitamin $E$, and a combination of vitamins $C$ and $E$, there was a significant increase in glutathion peroxidase activity ( $p$ $<0.05)$.

\section{Discussion}

Based on the results of the study found that there is the effect of rose aromatherapy to reducing the pain scale of postoperative. This is in line with research (Shaheen E. Lakhan et al. 2016). The Effectiveness of Aromatherapy in Reducing Pain: A Systematic Review and Meta-Analysis there are aromatherapy can successfully treat pain when combined with conventional treatments.

Aromatherapy refers to the medicinal or therapeutic use of essential oils absorbed through the skin or olfactory system. Some studies suggest that olfactory stimulation related to aromatherapy can result in immediate reduction in pain, as well as changing physiological parameters such as pulse, blood pressure, skin temperature, and brain activity. Although the benefits remain controversial, many patients and healthcare providers are attracted to aromatherapy because of its low cost and minimal side effects. Aromatherapy is most often used topically, or through inhalation. Smell and a sense of touch the $s$ produced by this oil can improve Pain Care.

\section{The effect of Vitamin $C$ on glutathion peroxidase activity in rats exposed to carbon tetrachloride.}

The results of the research shown in table 3 showed that there was a decrease in the average of glutathione peroxidase activity of rats which was presented with $\mathrm{CCl}_{4}(\mathrm{KP})$. This decrease in glutathion peroxidase activity was a result of the administration of carbon tetrachloride. The administration of carbon tetrachloride in the positive control group with the aim of increasing the condiiton of free radical / Reactive Oxygen Species (ROS). Rats exposed to $\mathrm{CCl}_{4}$ (positive control) glutathion peroxidase activity decreased their compared to the group not exposed to $\mathrm{CCl}_{4}$ (negative control).

When rats were given $\mathrm{CCl}_{4}$, lipid peroxide increased. In normal enzyme activity, an increase in substrate concentration, namely hydrogen peroxide (H2O2) molecules could increase enzyme activity. However, when the active side of all enzymes binded to the substrate, the addition of the substrate could not increase the speed of the next enzyme reaction, resulting in a decrease in GSH peroxidase enzyme activity.

In addition, free radical products could damage protein compounds because these oxidants could interact with amino acids making up proteins. The part that was easily attacked by free radicals was sulfidril $(\mathrm{SH})$ group. Free radical attack on these groups will form disulfide bonds (-S-S-) and cause intra and inter-molecular bonds so that proteins lost biological function. For example, proteins that act as enzymes would lose their activity (Winarsi, 2007). Therefore, the activity of the enzyme GSH peroxidase which was a complex protein molecule could experience a decrease in the presence of $\mathrm{CCl}_{4}$.

In table 3 showed that there was an increase in glutathione peroxidase activity in treatment group 1 (by administration of vitamin $\mathrm{C}$ ). The results of the analysis showed that there was a significant difference in the average activity of glutathion peroxidase between treatment groups. This was indicated by a $p<0.05$, which meant that there was an effect of vitamin $C$ on of glutathione peroxidase activity in rats exposed to carbon tetrachloride. 
The imbalance between antioxidants and free radicals could cause oxidative stress so that it took the intake of exogenous antioxidants, including vitamin $\mathrm{C}$ and $\mathrm{E}$. Vitamin $\mathrm{C}$ was a water-soluble antioxidant (aqueous antioxidant), while vitamin $\mathrm{E}$ was a fat-soluble antioxidant. The role of vitamin $\mathrm{C}$ as an antioxidant was an electron contributor to intracellular and extracellular biochemical reactions so that vitamin $\mathrm{C}$ was able to remove reactive oxygen compounds in cells. Vitamin $\mathrm{E}$ had the main function as a chain-breaking antioxidant. Vitamin $\mathrm{E}$ gave hydrogen from the hydroxyl group $(-\mathrm{OH})$ to the structure of free radicals so that free radicals became unreactive. Vitamin E stopped the fat peroxidation of free radicals by giving a single electron to form quinone tokoferil which was stable and perfectly oxidized therefore the presence of vitamin $E$ in the body was needed.

Vitamins $C$ and $E$ as antioxidants could stop free radical chain reactions. The mechanism of action of vitamin $\mathrm{E}$ in donating hydrogen ions to neutralize or reduce blood peroxide fat levels began with the work of $\alpha$-tocoferol radical which then changed to a-tocoferol perokside. From the two $\alpha$-tocoferol radicals it changed to a tocoferol dimer and finally became $\alpha$ tocoquinone which by vitamin $\mathrm{C}$ could be regenerated back to a-tocoferol (Hariyatmi 2004). Vitamin C along with vitamin $\mathrm{E}$ could inhibit the oxidation reaction by binding to the radical vitamin $E$ that formed in the process of breaking the free radical reaction by vitamin $C$ into free vitamin $E$ which refunctions as an antioxidant (Pavlovic et al. 2005). With these different working mechanisms, these two vitamins could inhibit the activity of free radicals.

Glutation peroxidase (GSHpx) was a peroxidase containing selenium (Se) on the active side. In the body, selenium worked together with vitamin $E$ as an antioxidant to slow down the oxidation of unsaturated fatty acids. With the intake of vitamins $C$ and $E$ could form optimal conditions for GSH peroxide enzyme activity, thus increasing the activity of enzymes in reducing hydrogen peroxide molecules and inhibiting cell damage.

The administration of vitamin $C$ to exposed rats affected on increasing the glutathion peroxidase activity because vitamin $\mathrm{C}$ was

a non-enzymatic antioxidant. Non enzymatic antioxidants worked by cutting off the chain oxidation reaction of free radicals or by catching it. As a result, radicals would not react with cellular components.

Vitamin C was widely known as an antioxidant. The strength of vitamin $\mathrm{C}$ as a water-soluble antioxidant was due to the ability of vitamin $\mathrm{C}$ to reduce. Vitamin C, among others, reduces superoxide to hydrogen peroxide, or $\mathrm{Fe}^{+}$became $\mathrm{Fe}^{+}$, or reduced other metal elements. After the transfer of one electron, vitamin $C$ produced monodehydroascorbate radicals. This radical would change to ascorbate and dehydroaskorbat. Most body tissues had glutathione-dependent

monodehydroascorbate reductase and NADPH enzymes which would reduce these radicals to re-ascorbate (Bender, 2003).

Vitamin C was a hydrophilic compound. This compound was the most important antioxidant in extracellular fluid. Vitamin C could efficiently prevent the formation of superoxide, hydrogen peroxide, hypochlorite, hydroxyl radicals, peroxyl radicals and oxidative radicals. Vitamin $\mathrm{C}$ was more effective in inhibiting fat peroxidation by peroxyl radicals when compared to other plasma components such as Vitamin E.

The results of this study were in accordance with the results of research conducted by Zulfita (2014), where the administration of rosella extract increased the activity of glutathion peroxidase in rats exposed to carbon tetrachloride. Vitamin C was what reduced the effects of free radicals caused by carbon tetrachloride, one of which was lipid peroxidase.

A number of epidemiological studies had examined the specific role of antioxidant nutrients. Vitamin $\mathrm{C}$ could cleanse $\mathrm{OH}$ which is very reactive, while consuming enough vitamin $E$ could prevent the spread of damage by free radicals in the biological membrane with its ability to cleanse peroxyl radicals (Tuminah, 2009). 


\subsection{The Effect of Vitamin $E$ on glutathion peroxidase activity in rats exposed to carbon tetrachloride}

In table 3 showed that there was an increase in the activity of glutahion peroxidase in treatment group 2 (by giving vitamin E). This was indicated by the value of $p<0.05$, which meant that there was an effect of vitamin $E$ on the activity of glutathione peroxidase in rats exposed to carbon tetrachloride.

This study was in line with the results of Rifdi's (2014) study, stating that mangosteen peel extracts increased glutathion peroxidase activity in rats exposed to carbon tetrachloride.

Vitamin $E$ was the largest fat soluble antioxidant in the cell's antioxidant defense system. The large role of vitamin $E$ protected cell membranes from oxidation by free radicals. Vitamin $E$ was located in the phospholipid layer of the cell membrane, so it was very effective in protecting damage to unsaturated fats (Almatsier, 2009).

Vitamin $E$ also had the main function as a chain-breaking antioxidant. Vitamin $\mathrm{E}$ gave hydrogen from the hydroxyl group $(-\mathrm{OH})$ to the structure of free radicals so that free radicals became unreactive. Vitamin $\mathrm{E}$ stopped the fat peroxidation of free radicals by giving a single electron to form quinone tokoferil which was stable and perfectly oxidized, therefore the presence of vitamin $E$ in the body was indispensable (Mark, 2000).

It can be concluded that the presence of vitamin $E$ in the body is very necessary, because vitamin $E$ can reduce the effects of free radicals caused by the administration of carbon tetrachloride.

\subsection{The Effect of combination of Vitamin $C$ and $E$ on glutathion peroxidase activity in rats exposed to carbon tetrachloride}

At the beginning of $\mathrm{CCl}_{4}$ poisoning, glutathion peroxodase activity decreased because free radicals increased in cells. Furthermore, to destroy the free radicals formed, exogenous antioxidants were needed to help endogenous antioxidants already presented in the body. This could be seen in table 3 where there was an increase in significant glutathion activity found in P1 compared to P2 and P3.

From the results of data analysis using Bonferroni's Post Hoc Test statistical test showed a significant difference in the average activity of glutathion peroxidase in all treatment groups. The combination of vitamins $\mathrm{C}$ and $\mathrm{E}$ for 14 days could significantly increased glutathion peroxidase activity. Possibly this was due to the combination of vitamins $C$ and $E$ in combination has the ability to counteract the effects of free radicals formed by giving one electron so that free radicals were not radical.

Vitamin E was known as an antioxidant that was able to stop the chain of free radical chain (chain-breaking antioxidants). By donating hydrogen, vitamin $E$ itself became oxidized vitamin E (Mark, 2000).

Oxidized vitamin $E$ that was formed could be generated by reducing compounds such as vitamin $C$, so vitamin $E$ returned to free vitamin $E$ and then could work again to break the chain of free radicals.

A number of epidemiological studies had examined the specific role of antioxidant nutrients. Vitamin $\mathrm{C}$ could cleanse $\mathrm{OH}$ which was very reactive, while consuming enough vitamin $E$ could prevent the spread of damage by free radicals in the biological membrane with its ability to cleanse peroxyl radicals (Tuminah, 2000).

Vitamins $C$ and $E$ as antioxidants could stop free radical chain reactions. The mechanism of action of vitamin $E$ in donating hydrogen ions to neutralize or reduce blood peroxide fat levels began with the work of radical $\alpha$-tocoferol which then changed to $\alpha$-tocoferol perokside. From the two $\alpha$-tocoferol radicals, it changed to $\alpha$ tocoferol dimer and eventually became $\alpha$ tocoquinone which by vitamin $\mathrm{C}$ could be regenerated back to $\alpha$-tocoferol (Hariyatmi 2004). Vitamin $C$ along with vitamin $E$ could inhibit the oxidation reaction by binding to the radical vitamin $E$ that formed in the process of breaking the free radical reaction by vitamin $E$ into free vitamin $E$ which refunctions as an antioxidant (Pavlovic et al. 
2005). With these different working mechanisms, if these two vitamins were used it could inhibit the activity of free radical.

Glutation peroxidase (GSHpx) was a peroxidase containing selenium (Se) on the active side. In the body, selenium worked together with vitamin $\mathrm{E}$ as an antioxidant to slow down the oxidation of unsaturated fatty acids. With the intake of vitamins $\mathrm{C}$ and $\mathrm{E}$ could form optimal conditions for GSH peroxide enzyme activity thus it could increase the activity of enzymes in reducing hydrogen peroxide molecules and inhibiting cell damage.

The higher the exogenous antioxidant intake, the higher the endogenous antioxidant status

\section{References}

Almatsier S. (2009). Basic Principles of Nutritional Sciences. Jakarta. PT. Gramedia Main Library.

ATSDR (Agency for Toxic Substances and Disease Registry) 2005. Toxilogikal profile for carbon tetraclorida. Atlanta GA: US. Department of Public Health and Human Services Public Health Service. Nutritional Biochemistry of the Vitamins. Cambridge University Pres. Ed 2 nd.

Chevion, S. et al, (2003). Plasma antioxidant status and cell injury after severe physical exercise. Proc Nati Acad Sci. 100 (9), pp. 5119-5123.

Cochrane G.C. (1991). Celluler injury by oxidants. Am.J. Med. Department of Immunology, IMM12, Research Institute of Scripps Clinic, North Torrey Pines Road, 92037, La Jolla, CA, USA. Pp. $177-188$

Dahiru D, ObiO and Umaru H. (2003). Effect of hibiscus sabdariffa calyx extract on carbon tetrachloride induced liver damage. Biochemistry 15 (1), pp. 27-33

Daruningrum I. (2012). Measurements of GSH levels in rat liver and rat blood. Practicum Report on Oxidative Metabolism and Stressas Techniques. Biomedical Masters Program in Medical Sciences, University of Indonesia. Jakarta.

Ernawati F. (2009). The effect of Vitamin C supplementation is campared with multivitamin mineral on antioxidant nutrisional status in women workers. Faculty of Human Ecology, Bogor Agrycultural University. Indonesian Nutrition Journal.

Farrell G. (2008). Cirrhosis in Asians: Less Common Than In Europeans. Journal of Gastroenterology and Hepatology, 23 (4).

Halliwel B. , Gutteridge J.M. (2004). Free radicals in biology and medicine Oxford.

Hariyatmi, (2004). The abilityof Vitamin E as an antioxidant against free radicals in the enderly. MIPA Journal Surakarta. UMS.14(1).
(Lampe, 1999), soit could suppress excessive cell damage and maintain antioxidant status (Winarsi, 2007). This situation could be seen from the results of the study, that by giving a combination of vitamins $C$ and $E$ could significantly increase glutathione peroxidise activity in rats exposed to carbon tetrachloride.

\section{Conclusion}

Vitamin E administration significantly affects the increase in glutathion peroxidase activity in rats exposed to carbon tetrachloride.

Lampe J.W. (1999). Health effects of vegetables and fruit: Assessing Mechanism of Action In Human Experimental Studies.

Marks Dawn B., Alan B. Marks, Smith Collen M., (2000). Basic medical biochemistry: a clinical approach. In Dr. Brahm U: Translator. EGC. Jakarta.

Montgomery K. F., Osborn L., Hession C., Tizerd R., Goff D., Vasallo C., et al. (1991). Activation of EndothelialLeukocyte Adhesion Molecule 1 Gene Transcription. Proc Natl Acad Sci USA. 88, pp. 6523-6527

Ogeturk M., Kus I., Kavakli A., Zararsiz I., Ihan N., Sasilmaz M. (2004). Effects of melatonin on carbon tetrachloride-induced changes in rat serum. J Physiol Biochem. 60 (3), pp.205-210

Pavlovic V., Cekic S., Rankovic G. \& Stoiljkovic N. (2005). Antioxidant and Pro-oxidant Effect of Ascocbic Acid. Acta Medica Medianae. 44 (1): 65-69.

Ramanathan K., Anusuyadevi M., Shila S., Paneerselvam C. (2005). Ascorbic acid andtocopherol as potent modulators of apoptosis on arsenic induced toxicity in rats. Toxicol Lett. 156, pp. 297-306.

Rendon-Remisez A., Cerbon-Solorzano J., MaldonadoVrga M., Quintanar-Escorza M. A., Calderon-Salinas J.V., (2007). Vitamin $E$ reduces the oxidative damage on aminolevunic dahidratase induced by lead intoxication in rat erythrocytes. Toxicology in vitro. 21, pp. 1121.

Sastroasmoro, Sudigdo, Ismael, Sofyan. (2011). The basics of clinical research methodology. 4th Edition. Jakarta: Sagung Seto.

Tuminah S. (2009). Media Penelit. dan Pengembang. Kesehat. XIX (Suplemen II), pp.S13-S20 
Int J Adv Life Sci Res. Volume 2(2)12-20

Valko, (2006). Free radicals, metals and antioxidants in oxidativestress-induced cancer. J Chem. Biol. Rusia. Edisi 160, pp. 1-40.

Winarsi H., (2007). Natural antioxidants and potential free radicals and their applications in health. Yogyakarta. Kanisius.

WHO, (2007). Carbon Tetrachloride Health And Safety Guide. Available from :

http://www.inchem.org/documents/hsg/hsg/hsg108.htm.
Youngson R. (2005). Antioksidan: Manfaat Vitamin C dan E bagi Kesehatan. Terjemahan oleh Susi Purwoko, Jakarta, Penerbit Arcan, 1.

Zulfita, (2014). Effect of rosella extract on Glutathione Peroxidase activity in rats exposed to Carbon Tetrachloride. (Thesis). Padang. Faculty of Medicine, Andalas University. 